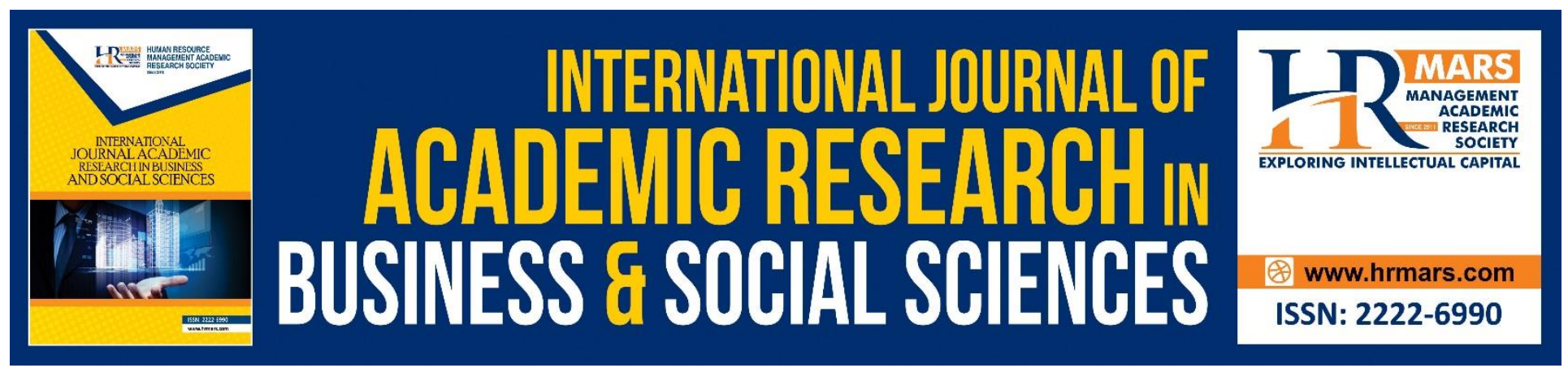

\title{
Compensation Management and Employee Performance in Nigeria
}

\author{
Onuorah Anthonia. N \\ Okeke, M.N \\ Ibekwe Anthony Ikechukwu
}

To Link this Article: http://dx.doi.org/10.6007/IJARBSS/v9-i2/5552 DOI: $10.6007 /$ IJARBSS/v9-i2/5552

Received: 22 Jan 2019, Revised: 26 Feb 2019, Accepted: 13 March 2019

Published Online: 20 March 2019

In-Text Citation: (Onuorah, Okeke, \& Ikechukwu, 2019)

To Cite this Article: Onuorah, A. N., Okeke, M. N., \& Ikechukwu, I. A. (2019). Compensation Management and Employee Performance in Nigeria. International Journal of Academic Research in Business and Socal Sciences, 9(2), 384-398.

\section{Copyright: (C) 2019 The Author(s)}

Published by Human Resource Management Academic Research Society (www.hrmars.com)

This article is published under the Creative Commons Attribution (CC BY 4.0) license. Anyone may reproduce, distribute, translate and create derivative works of this article (for both commercial and non-commercial purposes), subject to full attribution to the original publication and authors. The full terms of this license may be seen

at: http://creativecommons.org/licences/by/4.0/legalcode

Vol. 9, No. 2, 2019, Pg. 384 - 398

http://hrmars.com/index.php/pages/detail/IJARBSS

JOURNAL HOMEPAGE

Full Terms \& Conditions of access and use can be found at http://hrmars.com/index.php/pages/detail/publication-ethics 


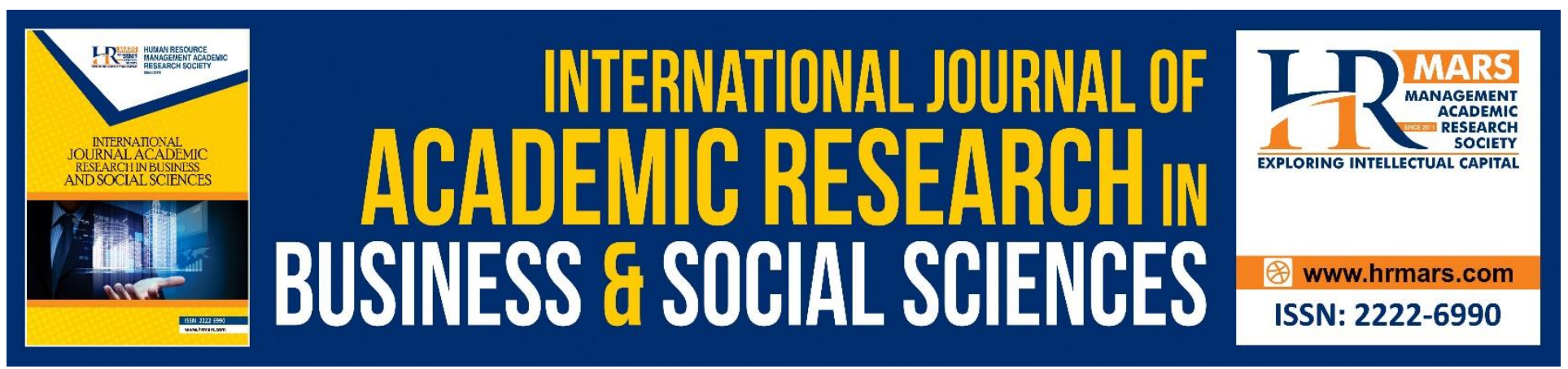

\title{
Compensation Management and Employee Performance in Nigeria
}

\author{
Onuorah Anthonia. N \\ Lecturer, Department of Business Administration, Chukwuemeka Odumegwu Ojukwu University, \\ Nigeria \\ Email: lawtonia@yahoo.com
}

\begin{abstract}
Okeke, M.N
Lecturer, Department of Business Administration, Chukwuemeka Odumegwu Ojukwu University, Nigeria
\end{abstract}

Ibekwe Anthony Ikechukwu

Lecturer, Department of Business Administration, Chukwuemeka Odumegwu Ojukwu University, Nigeria

Email: Ibekweangela26@gmail.com

\begin{abstract}
This study examine the effect of compensation management and employee performance in Nigeria organization. The study aim at investigating the influence of performance based compensation, competency-based-compensation and equity based-compensation on employee performance. Relevant conceptual, theoretical and empirical literatures were reviewed. The study was anchored on Human Capital Theory and Expectancy Theory. The study adopt descriptive survey research design.

The study was carried out in Anambra State. The population of the study comprises 257 public secondary schools in Anambra State. The sample size for the study consists of 257employees drawn from the population of the study. The sample consists of entire population. The instrument for data collection is a structured questionnaire. The face content validity of the instrument was employee. The instrument was trial-tested on a representative sample of 20 employee randomly selected of Anambra State. In analyzing the data for the null hypotheses, Z-test was be used to test the hypotheses at 0.05 level of significance. Equity based compensation has no negative significance effect on employee performance in Nigeria organization. Competency based compensation has no negative significance effect on employee performance in Nigeria organization. Performance based compensation has no negative significance effect on employee performance in Nigeria organization. Therefore the study conclude that compensation management has significance effect on employee
\end{abstract}


INTERNATIONAL JOURNAL OF ACADEMIC RESEARCH IN BUSINESS AND SOCIAL SCIENCES Vol. 9, No. 2, Feb, 2019, E-ISSN: $2222-6990$ ๑ 2019 HRMARS

performance in Nigeria organization. The study recommends that every organization should make equity-based compensation as compulsory policy since equity-based compensation are used more extensively in firms for ensuring maximum performance. Every organization should formulate competency-based compensation policy, the only thing standing between the employees and a greater wage is how much they contribute and how well they perform. Management should have Performance-based compensation plans at program at every level of an organization.

Keywords: Performance Based Compensation, Competency-Based-Compensation, Equity BasedCompensation and Employee Performance

\section{Introduction}

In the age of global competition, it is very essential to identify and retain the efficient, competent and knowledgeable employees in organization by developing and maintaining an effective compensation program for getting the best job performance from the employee (Akter and Moazzam 2016).Employees are the organization's key resource and the success or failure of organizations center on the ability of the employers to attract, retain, and reward appropriately talented and competent employees. Employees' willingness to stay on the job largely depends on compensation packages of the organization (Armstrong, 2003). In an attempt to ensure employees optimal performance and retention, organizations need to consider a variety of appropriate ways to reward the employees to get the desired results (Falola, Ibidunni and Olokundun 2014). It has been argued that the degree to which employees are satisfied with their job and their readiness to remain in an organization is a function of compensation packages and reward system of the Organisation (Fadugba, 2012).

Adeniyi (2013) posit that the fundamental tasks in human resources management is compensation management. It is a complex task that occurs periodically, demand accuracy and must not be delayed. Compensation management requires integrating employees' processes and information with business process and strategies to achieve optimal organizational goals and objectives (Adeniyi 2013). This can be attributed to the fact that compensation management is an essential tool to "integrate individual efforts with strategic business objectives by encouraging employees to do the right things with ever improving efficiency. (Adeniyi, 2013). In other words, compensation management is' a powerful means of focusing attention within an organization. They send clear .messages to all employees of the, organization informing them about expected attitudes and behaviors (Schell and Solomon, 2007).

Milkovich and Newsman, (2002) argued that compensation management system can create and sustain a competitive advantage for organizations. In recent years, the inclusion of non-financial measures has gained some popularity in compensation management, while some schools demonstrate positive effects of incorporating non- financial measures in to the compensation management system empirically (Widmier, 2002). He further states that, human resources model of compensation generally assume that higher performance requires greater effort or that is in some other ways associated with disutility on the part of workers. In other to provide incentives, these models predict the existence of reward systems that structure compensation so that a worker expected utility increase with' observed productivity. 
Compensation packages entail some basic features that tend to make employees satisfy on their job amongst which includes salaries, bonuses, incentives, allowances, promotion, recognition (Werner 2001) All these have significant impact on employees' performance (Martineau Lehman Matwa Kathyola and Storey 2006). However, to avoid wrong perception and controversy by the employees, compensation system must be clearly communicated to employees with job measurement which will drive the much needed performance in the employees (Yamoah2013). Hsin-His, (2011) posit that compensation is a significant tool in human resources. An effective compensation system design significantly influences organizational development by revealing external competitiveness, internal equity and individual equity. External competitiveness attracts talent, and internal equity helps companies to retain talent by ensuring that employees and colleagues making the same contributions obtain the same compensation. Individual equity allows employees to feel that their potential is fully rewarded; thus, they are encouraged (Hsin-His2011).Although compensation means something different to individuals, organizations and society, it is important to all. For individuals, compensation is not only the return of benefits, but it also reflects on individuals' capabilities or achievements (Ali, 2009). For organizations, compensation is a cost or expenditure, as well as an important tool to obtain competitive advantages. Within society, compensation not only influences wealth distribution, but also symbolizes social equity and justice (Hsin-His, 2011).

\section{Statement of the Problem}

The compensation practices includes not only salary, but also the direct and indirect rewards and benefits the employee is provided with in return for their contribution to the organization. Some of the benefits of employee's performance include health insurance, disability income protection, retirement benefits, daycare, tuition reimbursement, sick leave, vacation (paid and no-paid), funding of education as well as flexible and alternative work arrangements. Compensation is usually narrowed to cash and as a result, employers only have a tunneled vision when it comes to the issues of compensation for their employees. Other aspects of compensation which makes up the total compensation package for the employee are not given much attention. Employees themselves fail to recognize the fact that their compensation is a package and not only related to cash. The byproduct of the above understanding of compensation is that it is poorly managed and most of the time performance is affected adversely. Therefore the problem the researcher intends to investigate the effect of performance based compensation plans, merit-based-compensation, competency-basedcompensation and equity based-compensation on employees performance and understand what contributes to total compensation and how it can be better managed and linked to employee performance

\section{Objective of the Study}

The general objective of this study was to examine the influence of compensation management and employee performance in Nigeria organization. Specific objectives are to:

1. Examine the relationship between performance based compensation on employee performance in Nigeria organization.

2. Determine the relationship between equity based compensation and employee performance in Nigeria organization. 
INTERNATIONAL JOURNAL OF ACADEMIC RESEARCH IN BUSINESS AND SOCIAL SCIENCES

Vol. 9, No. 2, Feb, 2019, E-ISSN: 2222-6990 C 2019 HRMARS

3. Investigate the relationship between competency based compensation and employee performance in Nigeria organization.

\section{Research Question}

1. What are the extent of relationship between performances based compensation and employee performance in Nigeria organization.

2. What are the extent relationship between equity based compensation and employee performance in Nigeria organization.

3. To what does competency based compensation relate with employee performance in Nigeria organization

\section{Hypotheses}

$\mathrm{Ho}_{1}$ : Performance based compensation has no significance relationship with employee performance in Nigeria organization.

$\mathrm{Ho}_{2}$ : Equity based compensation has no significance relationship with employee performance in Nigeria organization.

$\mathrm{Ho}_{3}$ : Competency based compensation has no significance relationship with employee performance in Nigeria organization.

\section{Literature Review \\ Concept of Compensation}

Compensation is all forms of financial returns and tangible services and benefits employees receive as part of an employment relationship (Akter and Moazzam2016) compensation surrounded by the employee wages and salaries, incentive-payments, bonuses, and commissions. Employee compensation contains all forms of pay and rewards received by employees for the performance of their jobs" (Snell \& Bohlander, 2010). According to Dessler (2011) employee compensation means all forms of pay or rewards going to employees and arising from their employment and it may be direct financial payments (Pay in the form of wages, salaries, incentives, commissions, and bonuses) and indirect financial payments (Pay in the form of financial benefits such as insurance).

Performance-Based-Compensation: In 1988, Baker, Jensen, \& Murphy provided an explanation on performance-based compensation plans, indicates that explicit financial rewards are an important part of a worker's compensation. Delery and Doty 1996 in Akter and Moazzam (2016) demonstrated performance-based compensation as the single strongest predictor for job performance. Furthermore, a study conducted on compensation and performance (Pfeffer, 1998 in Akter and Moazzam 2016) associated with performance-based incentive program at every level of an organization. Besides that, Banker, Lee and Potter (2000) focused on performance- based compensation which increase an organization's overall productivity by attracting and retaining more productive employees. In contrast, individual performance evaluation may involve discretion and subjectivity, as well as nonfinancial and financial performance criteria which also concerns with the compensation policy and strategy. 


\section{Competency-Based-Compensation}

The word competency was brought into the public arena in the USA in the early 1980s by Boyatzis (1982). He defined competency as an underlying characteristic of an individual which is causallyrelated to effective or superior performance. According to Liebegott (2015), Competency-based compensation policy is a pay structure that rewards employees based on how well they perform in the workplace, rather than the hierarchy of their position or years of experience. With a competencybased compensation policy, the only thing standing between the employees and a greater wage is how much they contribute and how well they perform. With this method employees often more likely to take a greater initiative and contribute competitive advantage for the organization. For creating a culture of self-improvement and wide productivity is through a competency-based compensation policy or structure. This compensation structure offers a tangible reward for the employees who are dedicated to growing their skills and improving themselves. When the employees dedicate their timeeven outside of the 40-hours per week to growing organization's products and services, they will not only contribute to the success of the company, but also be motivated by the compensation structure they receive for their dedication from the organization

(www.knowledgewave.com/blog/competency-based-pay-structure).On the other hand, Competency or skill_based pay is a compensation system that rewards employees with additional pay in exchange for formal certification of the employee's mastery of skills, knowledge, and/or competencies (Gerald et al., 2011). Besides, Armstrong and Brown (1998), investigated that competency frameworks have a role in main HR functions in as many as 70 per cent of organizations and competencies are used mainly in performance management, recruitment and selection, and training and development (Competency and Emotional Intelligence Benchmarking Survey, 2002). However, this distinction is not always clear in the subsequent literature, or certainly in practice. Armstrong (1999), for example talks about "hard" or work-based competences which are expectations of job performance and the standards of outputs (Neathey \& Reilly, 2003).

\section{Equity Based-Compensation}

The general idea of equity based compensation is to offer employees a share of the company's future profits in exchange for lower (or sometimes zero) salaries up front. For maintaining equity -based compensation policy a consulting lawyer is needed before making any formal offers (Bhashyam, 2014). Equity based compensation not only lessens the up-front financial burden of paying out skyhigh salaries, but it also attracts employees who are committed to working harder in order to ensure their financial wellbeing and the success of the company. Equity compensation, no matter the form, is typically subject to restrictions. Most importantly, equity compensation is usually subject to vesting, which means that an employee must hit certain performance or time-based (more common) milestones in order for all of the stock. How much of one's compensation is in salary and how much is in equity depends less on the role (business development, engineer) and more on company maturity (https://equityzen.com/team). Equity-based pay spread at explosive rates in the United States during the 1990s. Morgenson, (1998) reports that in 1997, the 200 largest U.S. companies had reserved more than 13 percent of their common shares for compensation awards to managers, up from less than seven percent eight years earlier (Ofek \&Yermack, 2000). A study (Mehran 1995) showed that equity-based compensation is used more extensively in firms for ensuring maximum 
INTERNATIONAL JOURNAL OF ACADEMIC RESEARCH IN BUSINESS AND SOCIAL SCIENCES Vol. 9, No. 2, Feb, 2019, E-ISSN: 2222-6990 C 2019 HRMARS

performance. Arnolds and Boshoff (2002) demonstrated a link/relationship between the job performance, job satisfaction and individual personality differences on which there is a effect of equity based pay among people which are also related with compensation policy.

\section{Theoretical Framework}

The study is anchored on Human Capital Theory and Expectancy Theory

Human Capital Theory: Human capital signifies the combined the brainpower and experience of staff as a source of competitive improvement that cannot be imitated by rivals (Resick, 2007). This theory advocates for attracting, engaging, repayment and developing people in organizations. In the context of Agriculture and business sector. Some of the employee compensation practices in this research are meant to ensure that the performance of employees is improved this theory is relevant. However this theory has been criticized for not addressing other underlying components of employee performance. Scholars have argued that ultimately, it's only the characteristics that improve employee performance. This is because it considers reward which is also a factor of compensation. This means that employees can be rewarded for their efforts despite the fact that the theory does not examine the effect of the rewards.

Expectancy Theory: According to Armstrong, (2010), in the expectancy theory, motivation is likely to be when there is a perceived and usable relationship between and outcome, with the outcome being seen as a means of rewarding needs. In other words, there must be a relationship between a certain reward and what has to be done to achieve it. This theory is very important in the context of this research. It is instrumental especially when designing performance-based employee wellbeing programmes. This theory helps explain why an organization's staff would feel confident that they can grow in the same organization, hence remain there, or seek development elsewhere by exiting the organisation. 
INTERNATIONAL JOURNAL OF ACADEMIC RESEARCH IN BUSINESS AND SOCIAL SCIENCES

Vol. 9, No. 2, Feb, 2019, E-ISSN: 222 2-6990 (C) 2019 HRMARS

\section{Empirical Review}

\begin{tabular}{|c|c|c|c|c|}
\hline $\begin{array}{l}\text { Author/ } \\
\text { Year }\end{array}$ & Topic & Variables & Method & Remark/Conclusion \\
\hline $\begin{array}{l}\text { Adewale, } \\
\text { Adenike, } \\
\text { Hezekiah and } \\
\text { Heirsmac } \\
\text { (2014) }\end{array}$ & $\begin{array}{l}\text { The effect of } \\
\text { compensation } \\
\text { packages on } \\
\text { employees' job } \\
\text { performance and } \\
\text { retention in a } \\
\text { selected private } \\
\text { University in Ogun } \\
\text { State, South-West } \\
\text { Nigeria. }\end{array}$ & $\begin{array}{l}\text { Dependent } \\
\text { employees' } \\
\text { performance } \\
\text { Independent variable: } \\
\text { salary, } \\
\text { incentives, allowances, } \\
\text { and fringe benefits }\end{array}$ & $\begin{array}{l}\text { simple } \\
\text { percentage }\end{array}$ & $\begin{array}{l}\text { The results showed strong } \\
\text { relationship between } \\
\text { compensation packages and } \\
\text { employees' performance and } \\
\text { retention. The summary of the } \\
\text { findings indicates that there is } \\
\text { strong correlation between the } \\
\text { tested dependent and } \\
\text { independent variables (salary, } \\
\text { bonus, incentives, allowances, } \\
\text { and fringe benefits). However, } \\
\text { management and decision } \\
\text { makers should endeavour to } \\
\text { review compensation packages } \\
\text { at various levels in order to } \\
\text { earn employees' satisfaction } \\
\text { and prevention of high labour } \\
\text { turnover among the members } \\
\text { of staff. }\end{array}$ \\
\hline $\begin{array}{l}\text { Abdul, } \\
\text { Ramzan, } \\
\text { Hafiz, Ali and } \\
\text { Arslan (2014) }\end{array}$ & $\begin{array}{l}\text { The impact of } \\
\text { compensation on } \\
\text { employee } \\
\text { performance in } \\
\text { banks of Pakistan. }\end{array}$ & $\begin{array}{l}\text { Dependent variable: } \\
\text { employee performance } \\
\text { Independent variable: } \\
\text { salary, rewards, Indirect } \\
\text { Compensation }\end{array}$ & $\begin{array}{l}\text { Regression } \\
\text { analysis }\end{array}$ & $\begin{array}{l}\text { It is founded from different } \\
\text { results that Compensation has } \\
\text { positive impact on employee } \\
\text { performance. It is proved from } \\
\text { correlation analysis that all the } \\
\text { independent variables have } \\
\text { weak or moderate positive } \\
\text { relationship to each other. } \\
\text { shows that all the independent } \\
\text { variables have insignificant and } \\
\text { positive impact on employee } \\
\text { performance. Descriptive } \\
\text { analysis also reveals that all the } \\
\text { independent variables have } \\
\text { positive impact on employee } \\
\text { performance. ANOVA results } \\
\text { reveal that education have not } \\
\text { same impact on employee } \\
\text { performance. }\end{array}$ \\
\hline
\end{tabular}


INTERNATIONAL JOURNAL OF ACADEMIC RESEARCH IN BUSINESS AND SOCIAL SCIENCES

Vol. 9, No. 2, Feb, 2019, E-ISSN: 2 22 2-6990 (C) 2019 HRMARS

\begin{tabular}{|c|c|c|c|c|}
\hline $\begin{array}{l}\text { Odunlami } \\
\text { and Asabi } \\
(2014)\end{array}$ & $\begin{array}{l}\text { The effect of } \\
\text { compensation } \\
\text { management on } \\
\text { employees } \\
\text { Performance in the } \\
\text { Manufacturing } \\
\text { Sector, A case study } \\
\text { of A Reputable Food } \\
\text { and Beverage } \\
\text { Industry. }\end{array}$ & $\begin{array}{l}\text { Dependent } \\
\text { variable:Independent } \\
\text { variable: working } \\
\text { condition, employee } \\
\text { performance, } \\
\text { compensation } \\
\text { management }\end{array}$ & $\begin{array}{l}\text { Inferential } \\
\text { and } \\
\text { descriptive } \\
\text { statistics } \\
\text { Analysis of } \\
\text { Variance } \\
\text { (ANOVA). }\end{array}$ & $\begin{array}{l}\text { It shows that there is a } \\
\text { significant relationship } \\
\text { between good welfare service } \\
\text { and employees performance. } \\
\text { The f-statistics of } 12.052 \text { shows } \\
\text { that the model is statistically } \\
\text { significant. This shows that } \\
\text { there is a significant } \\
\text { relationship between } \\
\text { compensation management } \\
\text { and improved productivity. It } \\
\text { shows that is a significant } \\
\text { relationship between } \\
\text { compensation management } \\
\text { and employees performance. }\end{array}$ \\
\hline $\begin{array}{l}\text { Akter and } \\
\text { Moazzam } \\
(2016)\end{array}$ & $\begin{array}{lr}\text { The effect } & \text { of } \\
\text { compensation } & \text { (CN) } \\
\text { on (JP) } & \text { in } \\
\text { Chittagong, } \\
\text { Bangladesh }\end{array}$ & $\begin{array}{l}\text { Dependent variable: } \\
\text { job } \\
\text { performance } \\
\text { Independent variable: } \\
\text { proper strategy and } \\
\text { policy based } \\
\text { compensation scheme }\end{array}$ & survey & $\begin{array}{l}\text { The theoretical analysis } \\
\text { indicated that proper strategy } \\
\text { and policy based compensation } \\
\text { scheme can enhance the job } \\
\text { performance of the employees. } \\
\text { Because, employees will confer } \\
\text { the maximum effort for } \\
\text { providing best performance } \\
\text { when a compatible (with } \\
\text { current market situation) } \\
\text { compensation scheme is } \\
\text { offered and maintained by the } \\
\text { organizations. Thus, } \\
\text { compensation (CN) has a } \\
\text { significant effect on job } \\
\text { performance (JP). The } \\
\text { quantitative analysis } \\
\text { demonstrated that there is a } \\
\text { strong and positive relationship } \\
\text { between compensation and job } \\
\text { performance. }\end{array}$ \\
\hline $\begin{array}{l}\text { Hsin-Hsi } \\
\text { (2011) }\end{array}$ & $\begin{array}{l}\text { The influence of } \\
\text { compensation } \\
\text { system design on } \\
\text { employee } \\
\text { satisfaction } \\
\text { Taiwan. }\end{array}$ & $\begin{array}{l}\text { Dependent variable: } \\
\text { employee satisfaction } \\
\text { Independent variable: } \\
\text { job-based pay, skill- } \\
\text { based pay and } \\
\text { performance based pay }\end{array}$ & $\begin{array}{l}\text { Pearson } \\
\text { correlation }\end{array}$ & $\begin{array}{l}\text { The Pearson correlation test } \\
\text { hypotheses. An empirical } \\
\text { analysis demonstrates a } \\
\text { positive correlation between } \\
\text { employee satisfaction and job- } \\
\text { based pay, skill-based pay and }\end{array}$ \\
\hline
\end{tabular}


INTERNATIONAL JOURNAL OF ACADEMIC RESEARCH IN BUSINESS AND SOCIAL SCIENCES

Vol. 9, No. 2, Feb, 2019, E-ISSN: 2222-6990 C 2019 HRMARS

\begin{tabular}{|l|l|l|l|}
\hline & & $\begin{array}{l}\text { performance-based pay. In } \\
\text { addition, some demographic } \\
\text { variables reveal a moderating } \\
\text { effect on this relationship. }\end{array}$ \\
\hline
\end{tabular}

\section{METHODOLOGY}

The study adopt descriptive survey research design. The study was carried out in Anambra State. The population of the study will comprise 257 public secondary schools in Anambra State. The sample size for the study will consist of $257 \mathrm{employees} \mathrm{drawn} \mathrm{from} \mathrm{the} \mathrm{population} \mathrm{of} \mathrm{the} \mathrm{study.} \mathrm{The} \mathrm{sample}$ consists of entire population. The instrument for data collection is a structured questionnaire. The face and content validity of the instrument was employee. The instrument was trial-tested on a representative sample of 20 employee randomly selected of Anambra State. In analyzing the data for the null hypotheses, Z-test will be used to test the hypotheses at 0.05 level of significance.

\section{Presentation and Analysis of Data}

In this chapter the data collected were presented and analysed. The results were presented in tables 1 - 4 in accordance with the research questions and hypotheses. In analyzing the data, mean ratings from 1.00-1.49=very low; 1.50-2.49=low, 2.50=3.49=high; 3.50-4.00=very high.

Research Question 1: What are the extent of relationship between performances based compensation and employee performance in Nigeria organization.

Table 1: Mean score of Performances Based Compensation on Employee Performance

\begin{tabular}{|c|c|c|c|c|c|}
\hline & & $\mathbf{N}$ & Mean & Std. Deviation & Remark \\
\hline $\begin{array}{l}\text { Performances } \\
\text { Compensation }\end{array}$ & Based & 681 & 2.91 & .55 & High \\
\hline
\end{tabular}

The mean score of between performances based compensation e is 2.91 shown in table 1 above indicates that performances based compensation on employee performance is high.

Research Question 2: What are the extent relationship between equity based compensation and employee performance in Nigeria organization

Table 2: Mean Score of Equity Based Compensation on Employee Performance

\begin{tabular}{lllll} 
& N & Mean & Std. Deviation & Remark \\
\hline Male & 282 & 2.93 & .44 & High \\
Female & 399 & 2.90 & .61 & High
\end{tabular}

The mean score of equity based compensation 2.93 and 2.90 for equity based compensation employee performance in Table 2 shows that equity based compensation on employee performance is high. 
INTERNATIONAL JOURNAL OF ACADEMIC RESEARCH IN BUSINESS AND SOCIAL SCIENCES

Vol. 9, No. 2, Feb, 2019, E-ISSN: 2222-6990 C 2019 HRMARS

Research Question 3: To what does competency based compensation relate with employee performance in Nigeria organization?

Table 3: Mean score of Competency Based Compensation on Employee Performance

\begin{tabular}{|c|c|c|c|c|c|}
\hline & & $\mathbf{N}$ & Mean & Std. Deviation & Remark \\
\hline \multirow{2}{*}{$\begin{array}{l}\text { Competency } \\
\text { Compensation }\end{array}$} & Based & 526 & 2.90 & .56 & High \\
\hline & & 155 & 2.96 & .50 & High \\
\hline
\end{tabular}

The mean scores of competency based compensation 2.90 and 2.96 on employee performance indicate competency based on employee performance is high.

Test of Hypotheses

Ho: Performance based compensation has no significance effect on employee performance in Nigeria organization.

$\mathrm{H}_{1}$ : Performance based compensation has a significance effect on employee performance in Nigeria organization

Table 5: z-test Effect of Performance Based on Employee Performance in Nigeria Organization

\begin{tabular}{|c|c|c|c|c|c|c|c|c|}
\hline $\begin{array}{l}\text { Source } \\
\text { variation }\end{array}$ & of & $\mathbf{N}$ & Mean & SD & Df & z-cal & z-crit & Decision \\
\hline \multirow[t]{2}{*}{ Male } & & 282 & 2.93 & .44 & & & & \\
\hline & & & & & 697 & .90 & 1.96 & Not Sig \\
\hline Female & & 399 & 2.90 & .61 & & & & \\
\hline
\end{tabular}

The result in Table 5 shows that the calculated z-value (.90) is less than the critical value (1.96) at alpha level of 0.05 and degree of freedom (df) 697. This is an indication that the effect of Performance based compensation on employee performance was not significant. The null hypothesis therefore was not rejected. Therefore we can concludes that Performance based compensation has no significance effect on employee performance in Nigeria organization.

\section{Hypothesis Two}

Ho: Equity based compensation has no significance effect on employee performance in Nigeria organization.

$\mathrm{H}_{1}$ : Equity based compensation has no significance effect on employee performance in Nigeria organization. 
INTERNATIONAL JOURNAL OF ACADEMIC RESEARCH IN BUSINESS AND SOCIAL SCIENCES

Vol. 9, No. 2, Feb, 2019, E-ISSN: $2222-6990$ ๑ 2019 HRMARS

Table 6: z-test on Effect of Equity Based Compensation on Employee Performance in Nigeria

\begin{tabular}{|c|c|c|c|c|c|c|c|c|}
\hline $\begin{array}{l}\text { Source } \\
\text { variation }\end{array}$ & of & $\mathbf{N}$ & Mean & SD & Df & z-cal & z-crit & Decision \\
\hline Equity & Based & 526 & 2.90 & .56 & & & & \\
\hline \multirow{2}{*}{\multicolumn{2}{|c|}{ Compensation }} & & & & 679 & 1.17 & 1.96 & Not Sig \\
\hline & & 155 & 2.96 & .50 & & & & \\
\hline
\end{tabular}

As indicated in Table 6, the analysis shows that the $z$-cal value of 1.17 is less than the critical value of 1.96 at alpha level of 0.05 and degree of freedom (df) 679. This shows that the difference in the effect of equity based compensation on employee performance in Nigeria was not significant. Therefore, the null hypothesis of no significant was not rejected. We can says that Equity based compensation has no significance effect on employee performance in Nigeria organization.

\section{Hypothesis Three}

Ho: Competency based compensation has no significance effect on employee performance in Nigeria organization.

$\mathrm{H}_{1}$ : Competency based compensation has a significance effect on employee performance in Nigeria organization

Table 7: z-test on effect of Competency Based Compensation on Employee Performance in Nigeria organization

\begin{tabular}{|c|c|c|c|c|c|c|c|}
\hline $\begin{array}{l}\text { Source } \\
\text { variation }\end{array}$ & $\mathbf{N}$ & Mean & SD & df & z-cal & z-crit & Decision \\
\hline Competency & 532 & 290 & .54 & & & & \\
\hline Based & & & & 679 & .65 & 1.96 & Not Sig \\
\hline Compensation & 149 & 2.94 & .55 & & & & \\
\hline
\end{tabular}

The result in Table 7 shows that the calculated z-value (.65) is less than the critical value (1.96) at alpha level of 0.05 and degree of freedom (df) 679. This is an indication that the effect of competency based compensation on employee performance in Nigeria organization was not significant. The null hypothesis therefore was not rejected. Therefore, we conclude that Competency based compensation has no significance effect on employee performance in Nigeria organization.

\section{Summary of Findings}

The findings of the study are summarized as follows:

1. Equity based compensation has no negative significance effect on employee performance in Nigeria organization.

2. Competency based compensation has no negative significance effect on employee performance in Nigeria organization 
INTERNATIONAL JOURNAL OF ACADEMIC RESEARCH IN BUSINESS AND SOCIAL SCIENCES

Vol. 9, No. 2, Feb, 2019, E-ISSN: 2222-6990 C 2019 HRMARS

3. Performance based compensation has no negative significance effect on employee performance in Nigeria organization.

\section{Conclusion}

The study investigate compensation management and employee performance in Nigeria organization. From the analysis it was discover that Equity based compensation, Competency based compensation and Performance based compensation has no negative significance effect on employee performance in Nigeria organization. Therefore, the study conclude that compensation management has significance effect on employee performance in Nigeria organization.

\section{Recommendations}

Basing on the findings of the study, the following recommendations were made:

1. Every organization should make equity-based compensation as compulsory policy since equitybased compensation are used more extensively in firms for ensuring maximum performance

2. Every organization should formulate competency-based compensation policy, the only thing standing between the employees and a greater wage is how much they contribute and how well they perform.

3. Management should have Performance-based compensation plans at program at every level of an organization

\section{References}

Ali, P. (2009). Job satisfaction characteristics of higher education faculty by race. Afr. J. Bus. Manage, 4(5): 289-300.

Adewale, O, O., Adenike, A. A., Hezekiah O F. \& Heirsmac, P. T. (2014). Compensation packages: a strategic tool for employees' performance and retention. Leonard Journal of Science. 25 6584

Akter, N. \& Moazzam, H. (2016). Effect of compensation on job performance: An empirical study. International Journal of Engineering Technology, Management and Applied Science. 4, (8),

Ahmed, J.U. (2013). Human Resources Management practices in readymade garments industry of Bangladesh. University of Chittagong, Bangladesh.

Alnaqbi, W. (2011). The relationship between human resource practices and employee retention in public organisations: an exploratory study conducted in the United Arab Emirates. (Unpublished PhD thesis, Edith Cowan University, Australia).

Appelbaum, S. H., \& Mackenzie, L. (1996). Compensation in the year 2000: pay for performance? Health Manpower Management, 22(3), 31-39.

Armstrong, M., \& Brown, D. (1998). Relating competencies to pay: The UK experience. Compensation \& Benefits Review, 30(3), 28-39.

Arnolds, C. A., \& Boshoff, C. (2002). Compensation, esteem valence and job performance: an empirical assessment of Alderfer's ERG theory. International Journal of Human Resource Management, 13(4), 697-719. 
INTERNATIONAL JOURNAL OF ACADEMIC RESEARCH IN BUSINESS AND SOCIAL SCIENCES

Vol. 9, No. 2, Feb, 2019, E-ISSN: $2222-6990$ ๑ 2019 HRMARS

Bajor, J. K., \& Baltes, B. B. (2003). The relationship between selection optimization with compensation, conscientiousness, motivation, and performance. Journal of Vocational Behavior, 63(3), 347-367.

Banker, R. D., Lee, S. Y., Potter, G., \& Srinivasan, D. (2000). An empirical analysis of continuing improvements following the implementation of a performance-based compensation plan. Journal of Accounting and Economics, 30(3), 315-350.

Bloom, M., \& Michel, J. (2002). The relationship among organizational context, pay dispersion, and managerial turnover. Academy of Management Journal, 45: 33-42.

Borman, W. C. (2004). Introduction to the special issue: Personality and the prediction of job performance: More than the big five. Human Performance, 17(3), 267-269.

Brown, M. P., Sturman, M. C., \& Simmering, M. J. (2003). Compensation policy and organizational performance: The efficiency, operational, and financial implications of pay levels and pay structure. of Management Journal, 46(6), 752-762. Academy

Chew, J.C.L. (2004). The influence of Human resource management on retention of the core employees: An empirical study. (Unpublished PhD thesis, Murdock University).

Dessler, G. (2011). Fundamentals of human resource management. Pearson Higher Ed.

Ferdausy, S. (2015). Impact of globalization on Human Resources Management Practices of the private 27) commercial Basnks in Bangladesh. University of Chittagong, Bangladesh.

Falola H. O., Ibidunni A. S, Olokundun A. M. (2014). Incentives packages and employees' attitudes to work: a study of selected government parastatals in Ogun State, South-West, Nigeria. International Journal of Research in Business and Social Science IJRBS, 3(1), 2147-4478.

Herpen, V. M., Praag, V. M., \& Cools, K. (2005). The effects of performance measurement and compensation on motivation: An empirical study. De Economist, 153(3), 303-329. 37)

Hsin-His, L. (2011). The influence of compensation system design on employee satisfaction. African Journal of Business Management. 5(26), 10718-10723

Huselid, M. A., \& Becker, B. E. (2000). Comment on "Measurement error in research on human resources and firm performance: How much error is there and how does it influence effect size estimates?" by Gerhart, Wright, McMahan, and Snell. Personnel Psychology, 53: 835-854.

Jones, E., Chonko, L., Rangarajan, D., \& Roberts, J. (2007). The role of overload on job attitudes, turnover intentions, and salesperson performance. Journal of Business Research, 60(7), 663671.

Laitinen, E. K. (2002). A dynamic performance measurement system: evidence from small Finnish technology companies. Scandinavian journal of management, 18(1), 65-99.

Ledford Jr, G. E., \&Heneman III, H. G. (2011). Skill-Based Pay. Society for Human Resource Management, Alexandria, VA.

Liao, H., \& Chuang, A. (2004). A multilevel investigation of factors influencing employee service performance and customer outcomes. Academy of Management Journal, 47(1), 41-58.

Masood, T. (2010). Impact of Human Resources Management (HRM) practices on organizational performance. A mediating role of employee performance. (Unpublished PhD thesis, M. A. Jinnah University, Islamabad, Pakistan).

Martineau T., Lehman U., Matwa P., Kathyola J., Storey K. (2006). Factors affecting retention of different groups of rural health workers in Malawi and Eastern Cape Province, South Africa, 
Mehran, H. (1995). Executive compensation structure, ownership and firm performance. Journal of financial economics, 38(2), 163-184.

Neathey, F., \& Reilly, P. A. (2003). Competency-based pay. Institute for Employment Studies.

Ofek, E., \&Yermack, D. (2000). Taking stock: Equity_based compensation and the evolution of managerial ownership. The Journal of Finance, 55(3), 1367-1384.

Osibanjo A.O., Abiodun A.J., Fadugba, A.O. (2012). Executive perception of the impact of flexitime on organisationalperformamce: evidence from the Nigeria Private Sector, International Journal of Applied Behavioural Economics, IJABE, 1(3), 16-27.

Qureshi, M O. \& Sajjad, S.R. (2015). An empirical analysis of the impact of compensation on job performance and work-family conflict in the kingdom of Saudi Arabia- a correlation model. European Scientific Journal, 11(4), 1857-7881.

Rathnaweera, R.R.N.T. (2010).Do Human Resources Management Practices Impact Employee Satisfaction, Commitment or Retention? (Unpublished Master'sThesis, University of Agder).

Resick, G. (2007). The Measurement of Antecedents of affective, Continuance and normative commitment to the organization. Journal of Occupational Psychology, 63-68.

Sopiah, (2013).The Effect of Compensation toward Job Satisfaction and Job Performance of Outsourcing Employees of Syariah Banks in Malang Indonesia. International Journal of Learning \& Development, 3(2), 77-91.

Sozer, S. (2004). An evaluation of current Human Resources Management Practices in the Turkish private sector (Unpublished PhD Thesis, Middle East Technical University).

Werner, A. (2001) Motivation in human resource management, Cape Town: Oxford University Press. 587.

Yamoah, E. E. (2013). Relationship between compensation and employee productivity Singaporean Journal of Business Economics, and Management Studies, 2(1), 110-114. 